Changing Societies \& Personalities, 2018

Vol. 2, No. 2, pp. 143-160

http://dx.doi.org/10.15826/csp.2018.2.2.034

ARTICLE

\title{
Revolution and Modernity ${ }^{1}$
}

\author{
Victor Martianov \\ Institute for Philosophy and Law, Ural Branch of Russian Academy of Sciences
}

\begin{abstract}
Revolution simultaneously legitimises and denies the coordinate centre of the political order of Modernity. It is difficult to describe the historical evolution from the early industrial, class-national forms of political organisation to late or global Modernity other than in terms of a low-intensity revolution in the rate of social change. On the other hand, this permanent modernisation is not revolutionary in the sense that the periodic splits of elites, colour revolutions, coups and national liberation movements do not in and of themselves make demands for fundamental change in the value-institutional core of the political order of Modernity. The potential for a new revolution can be consequent only on a repudiation of Modernity in favour of an alternative political project having a greater capability for universalisation and totalisation. If, in legitimising its liberal consensus and nation-state models as the dominant political format of their synthesis, capitalism is the value-institutional quintessence of the political order of Modernity, it is precisely in challenges to capitalism, the liberal consensus and nationalism that provide the most obvious means for crystallising revolutionary movements. From such a perspective, capitalism increasingly comes up against the global limits of its expansion, with class ideologies degenerating into a fragmented, technologically-intermediated populism, and nationstates experiencing increasing pressure from alternative political formats (city networks, multinational corporations, etc.) as they attempt to preserve the model of the social state. While various discourses and social groups profess to play the role of revolutionary utopias
\end{abstract}

${ }^{1}$ The article is prepared with the support of RFBR grant No. 18-011-00211 "Social Consensus in Russia: Mechanisms for Ideological and Institutional Regulation". 
and subjects, in essence, their ability to present a totalising alternative to late Modernity remains an open question. A utopian systemic challenge to Modernity, connected with a morally more justified configuration and associated hierarchy of legitimate violence, is yet to emerge, whether from within Modernity or some source external to it. It is demonstrated that in the long term a serious (and possibly revolutionary) correction of the political order of modern societies will be capable of producing a rental transformation of capitalism and an expansion of the rent-class stratification mechanisms associated with precarisation, along with a reduction of social mobility trajectories and the prospects of active social groups.

\section{KEYWORDS}

revolution, violence, political order, legitimacy, modernity, late modernity, centre-periphery, global economics, political subject, consensus, rental society, precariat

\section{The Political Project of Modernity as a Permanent Revolution?}

Since all the ideological coordinates of the basic liberal consensus (Immanuel Wallerstein) are by definition reducible to it, revolution can be seen to form a sacred reference point in the political project of Modernity, a kind of event analogue of the Nativity of Christ in Christian chronology. In this constructed history, revolution appears freed from all references to divine prescriptions in the guise of the common will of the people regarding their common destiny. Therefore, as Ortega y Gasset aptly notes, "...referring to the uprisings of medieval peasants and burghers as the precursors of the revolutions of modern times testifies to a complete absence of historical intuition. Between them there is almost nothing in common. In rising up against his feudal masters, a medieval man was rebelling against the abuses of those masters. The revolutionary, conversely, does not rebel against abuses, but against the order of things" (Ortega y Gasset, 2016, p. 133). A revolution may create a heterarchy in which alternative sources of power are the condition for meaningful social changes but it is unable to maintain a stable political order associated with the daily regulation of the conflictual space of individual and collective freedom. As a result, "...the entire history of Modernity as the story of different societies faced with the 'absolute independence' of the individual can be represented as a series of successful and unsuccessful attempts to achieve and maintain public order" (Kapustin, 2010, p. 587).

Revolution is an initiating event for the political order of the New and Newest Times. However, it cannot provide final answers to the question of how the modern political order may be subsequently maintained. This order is one in which the initial principles of maximising both collective and individual autonomy entail endless contradictions and engender a mass of conflicts whose resolution can only be achieved with the institutional support of a hierarchy of values and interests in society. 
A study of the history of the political order of Modernity reveals a constant revision and re-creation of social hierarchies along with associated compromises. As a metaphor, revolution refers to an instant transfiguration, transmutation, resurrection and a new life; it appears as a chiliastic dream of a collective and instantaneous transition to an earthly paradise, or, in later ideological forms, a rational plan for the realisation of a utopia. However, revolution never definitively establishes anything in the constant movement and renewal of generations, social groups, technological structures, and the dominant configurations of values and interests. Therefore, the revolution never reaches its final goals, which are ostensibly connected with a total change in relations between man, society and state. The stratification of revolutionary agents in the course of revolution leads to the attainment of the most radical goals being determined by terror, purges and mutual annihilation of the revolutionaries, who seek to monopolise the revolutionary ideology as the new basis of power. If the monopolistic claim of the revolutionary subject is successful, the new political order will become totalitarian; however, a compromise is more typically established between the outgoing and rising classes, with any social contradiction entailed by the former tending to be replaced by another inherent to the latter. In any case, the temporal unfolding of the revolution invariably involves the instrumental incorporation of the revolution by the revolutionary political subject into new structures of political hegemony. In their attempts to fix and routinise the achievements of the revolution, the subjects of revolution seize the coercive apparatus of the state; however, in so doing, the revolutionaries are themselves inevitably overtaken by the logic of the reproduction of the political order, transforming them into a new bureaucracy.

If the usual political order is based on the legitimisation of violence, then the revolution appears both as the foundation of Modernity and as an ineliminable challenge to it. The revolution confirms in practical terms the primary liberal thesis that the social order is not eternal but is the work of human hands. However, this is also why, being divided between finite and imperfect people, it cannot become finalised or its laws remain absolute and unchanged. For this, people would have to live forever, without the succession of generations or the movement of history. The revolution generates a modern political order, which offers alternative and morally more convincing grounds for violence than those operated by the estate-monarchical Ancien Régime. Exemplary, classical revolutions concerned the demolition of the Ancien Régime, which did not possess the internal conditions and mechanisms for reform in the course of growing systemic contradictions of the changing social structure and background in which Christian values were being eroded by new practices introduced by capitalism: "the policy of the medieval 'petit bourgeois' was to counterpose the privileges of the nobility with exactly the same privileges. City guilds and communes were famous for their narrow, suspicious and selfish spirit even more so than feudal lords" (Ortega y Gasset, 2016, p. 138).

In other words, the revolution is inevitably rethought during the process of the institutionalisation of Modernity. From the initiating event, it is more confidently interpreted from the position of the new liberal consensus as political extremism, which threatens the modern political order. In this way, Modernity is simultaneously 
constituted by a legitimisation and a denial of the revolution, which, in destroying the Ancien Régime, brought it into existence. Institutional Modernity, then, is wholly derived from the revolutionary event that engendered it. Revolution appears as the transcendental centre of Modernity, to which, however, it does not belong completely, and therefore eludes attempts at complete control. However, at the same time, the above-noted centre legitimises this order from a sacred-symbolic space in which everyday and routine legitimation procedures lose their power. Moreover, the question of a destructive/creative incursion or a return of this sacrosanct centre to the political order of Modernity always remains open. In connection with this, the political order of Modernism, as an epiphenomenon of the revolution, constantly strives to gain independence from it with the help of all kinds of institutions and procedures that aim to ensure its repeatability, its immutability and its self-identity outside of historical time.

With a more detailed examination of contemporary political ontology, it can be noted that the ineradicable contradiction between the modern political order and revolution is not necessarily fatal. It can be said that, following the establishment of the revolution-event, Modernity represents the same revolution, but a low-intensity revolution, unfolding across a long period of historical time. This is the undulatory or wave-like revolution that continues after the big bang that caused it and is associated with the endless changes and reconfigurations of the value-institutional core of the emergent society. However, if the basic legitimacy of the political order of Modernity always refers to the revolution, to the fact that we continue to live within this unfolding historical event mediated by many years and generations, then an obvious question arises: in what can a revolutionary change consist here and now against the background the fact that modern society is based on the tradition of progress - of constant improving changes - as a social norm? Modern societies may no longer require total revolutions. More important is the search for subtler socio-cultural adjustments that determine the effectiveness of the progress of each particular society. In such a system of coordinates, the absolute can only consist in change itself as a value.

Modernity counterposes the new morality of change to the customary morality of tradition, while at the same time strongly defending itself against any other radical changes that could undermine the new world. According to the thought of Jean Baudrillard, Modernity "gives rise to a crisis of values and moral contradictions. Thus, as an idea in which a whole civilisation recognises itself, modernity assumes a regulatory cultural function and thereby surreptitiously rejoins tradition." (Baudrillard, 1985 , p. 424). Here arises the image of Modernity as a new tradition of controlled changes in the turbulent social order. In such a context, the true revolution will consist in a total rejection of the political project of Modernity. Since it is only revolution that can become a new absolute event (Filippov, 2006, p. 108), superseding Modernity in favour of a totalised alternative, an event that rejuvenates the very system of modern ideological coordinates that is substantiated by the liberal consensus. In the meantime, in place of total rejection, it is possible to observe predominantly limited utopias caused by the internal contradictions of Modernity, which are, however, 
unlikely to consist in its potential alternatives. These include, for example, the logic of postmodernism, acting as a method of intellectual self-criticism and self-correction of late Modernity (Martianov, 2012).

The only revolution became a possibility within the new linear timeframe of Modernity, in which there exists a utopian discourse concerning a possible alternative future capable of being realised in the space of collective freedom. This contradicts previous cyclical concepts of time, in which the future is predicated by the present, and the recurrence of historical cycles does not entail significant differences that would allow the past to be distinguished from the present and the future as fundamentally different states of society. At the political centre of the Ancien Régime was the pre-ordained divine tradition; this is essentially what was refuted by rationally utilitarian and liberal Modernity. All the subsequent revolutions within Modernity were naturally limited in character, since either comprising the victories of nations in the struggle for sovereignty and independence; or were presented as counter-revolutions in the form of partial kickbacks to the Ancien Régime; or they only led to a rotation of the elites and an upgrade of the existing version of Modernity in the given society. This is the case irrespective of whether we are discussing the version of late Modernity, ideas about multiple modernities or the alternative project of Soviet Modernity. In all cases, we are dealing with invariants within the self-referential system of Modernism, which draws its legitimacy from the original act of its creation. This even applies, for example, in the case of the USSR, when the rational interpretation of the revolution as a whole still fits into the logic of liberal consensus in terms of its radical socialist invariant.

Moreover, the currently observed colour revolutions taking place under the conditions of late Modernity do not assume an analogous level of system development of the alternative political project, being essentially a discourse of cultural reconstruction, whether involving the logic of optimisation, reform or correction of the liberal consensus and capitalist ontology, but never implying a direct repudiation of the latter. Therefore, neither the struggle for sovereignty and periodic collapse of empires nor political upheavals or transition to different version/model of Modernity can properly be referred to in terms of revolution, any more than the dozens of other cases of political convulsion taking place in specific modern societies. This is true even if the results of the latter, thanks to symbolic politics and the construction of another collective memory, become a palliative reference point in the chronology of the new political regime. Thus, in fact, humanity has not yet experienced any new revolutions since the pulling down of the Ancien Régime. Significant transformations of individual societies were associated primarily with a global transition to Modernity and then to its late value-institutional versions. Against this background, the historical transformation of the project of Modernity is yet to lead to its revolutionary displacement of the alternative political project, despite all the fundamental differences between earlyindustrial, class and national Modernity variants and its later versions taking the form of second, global, radical, fluid or singular Modernity.

In abandoning reliance on tradition, the value centre of the political order of Modernity acquires a multifaceted character, which becomes the subject of 
permanent coordination and recognition by key social groups. Institutionally, it is constantly adjusted under the influence of parties, regions, ideologies, classes, states and endless co-ordination procedures: the activities of bodies of different branches of government, elections, referendums, public-political and trade union activities, mass communications, international interactions, etc. All these subjects of influence are in themselves ambivalent: they can support, change and/or destroy the basic liberal consensus that lies at the foundation of Modernity. Moreover, all these particular entities themselves claim ideological representation of the whole. Therefore, in modern nations, the centre is always divided and implicit, being the subject of constant discussion or bargaining. However, any danger, catastrophe or external threat leads to a mobilisation of society, during the course of which the value centre is manifested and consolidated.

The post-revolutionary stabilisation of a modern society is achieved by means of a consistent differentiation and empowerment of the subsystems of society in terms of the private conflicts that arise within them. Here, it is necessary to ensure that the latter are solved at the lower and middle levels, not generalising and not ultimately covering the entire social system (Luhmann, 2006). The paradox consists in the fact that the constant accumulation of internal contradictions never reaches a critical level. In every subsystem of society - politics, economics, law, art, etc. - special mechanisms for coordinating interests and facilitating partial, gradual changes that prevent revolutionary scenarios are being elaborated. On the basis of this modern political order, feudal political power was divided into autonomous spheres, in which private ownership, for the first time, became relatively independent of power (i.e. power ceased to be directly equivalent to ownership). As a result, politics as a zero-sum game, in which the winner takes all, became a means of permanently reconciling social interests within a preestablished time period (Ankersmit, 2002). Complicated procedures for instrumental, day-to-day legitimation of the political order of Modernity, e.g., elections, referendums, rotation of elites, reconciliation of class and/or civil interests, turn the revolution into a ritual political reference point. The possibility of revising the conditions of social consensus through the political participation of citizens and the rotation of elites significantly reduces the severity of conflicts and limits the possibilities for their totalisation. An important role in smoothing political contradictions is played by the division of Modernity into elective and functional bureaucratic elites, which allows the day-to-day, rational-functional goals of the state apparatus to be combined with the setting of strategic goals related to a reconciliation of the interests of the dominant social groups. The processes of systemic differentiation naturally lead to modern citizens being increasingly unwilling to place high hopes in the revolution under the conditions of a growing autonomy within private life and the structurally autonomous subsystems of modern society that limit the political sphere.

Nevertheless, the modern political order always contains the seeds of future revolution. Appeals to the revolution in the context of legitimising and rhetorical power (in the case of its opponents, critical and practical) reveals the utopian space of the political order of Modernity, proving that it is still capable of further improvement in public laboratories and unpredictable social experiments - and 
therefore, in principle, a candidate for early abolishment in favour of an alternative project. Therefore, the revolutionary challenges - whether cultural, economic, political - simply cannot accumulate in a sufficient volume for their own revolutionary resolution. A flexible political order either eliminates the initial causes of social unrest or actively incorporates new social forces. If it fails in this, a general reconfiguration takes place, during which meaningful social groups achieve recognition and places at the common table, thus establishing a new equilibrium.

From this perspective, if the revolution consists in a disruption of the state, then it is only natural if the political logic of the state and the revolution are embroiled in insoluble conflict. According to the latest theories of the revolutionary process, it is not so much the historical class struggle as an elementary crisis of legal competency or a default on obligations to the population on the part of the government that in most cases becomes the mechanism by which broad social movements and revolutions uncontrolled by the elites are launched (Goldstone, 2012; Skocpol, 1979). In the first instance, the triggering factors tend to be default, malfunction, disintegration and delegitimisation of the state (political order). The revolution appears in the form of the establishment of a total self-organisation of society in the transition to a new social equilibrium by means of collective practices and institutions. A space of collective freedom for the realisation of various political utopias arises together with a new state assembly. Here, an appeal to preservation of the political order (constitution, law, tradition) as a basic, unconditional value is directly comparable in terms of conferring political legitimacy with revolutionary calls for overthrowing this order. Moreover, values associated with maintaining order prevail in the eyes of citizens under conditions of stability and the competency of the state; that is, during the overwhelming majority of history, except in situations of crisis and the collapse of states. In this context, locking in the results of the revolution is always connected with compromises, with the collapse and/or betrayal of utopias in favour of reaction and various conservative kickbacks. Trade-off solutions, in principle, do not suit any of the social forces; however, they eventually allow them to be reconciled with them in exchange for ending the debilitating struggle between asserting a new utopia or maintaining the old order. Sooner or later the state is once again recognised as an indispensable public good and a kind big brother.

In the context of the interconnected world economy of late Modernity, substantial doubts concerning the possibility of a classical revolution at the scale of individual states are raised due to their growing global interdependence. National communities are increasingly becoming only private moments in the movement of more general background processes associated with an accumulation of the contradictions inherent in capitalism as well as demographic, technological and institutional transformations entailed by late-modern societies. In this situation, it makes little difference what kinds of social forces in a particular society invoke and uphold the mechanisms of social change, whether these be counter-elite, marginalised, precarious, working class, middle class, liberation movements, different minorities, etc.

From this perspective, a given state can be considered as merely an initial platform for the permanent global revolution. This key idea was carried by the political 
thought of the left throughout the entire twentieth century. Actually, the problem is of a rather different nature, viz. whether it is possible to initiate a revolution under conditions when the elites and the majority of citizens are as close in terms of their human qualities, their initial rights, education, morals and opportunities as never before in history? Accordingly, the revolution, both as a concept and as an event, is increasingly seen in metaphorical terms. As such, it is subject to constant deferment, which becomes comparable to eternity. At the same time, mechanisms for procedural legitimisation of changes within the tradition of modernity are strengthened in the form of a permanent reconfiguration of the value-institutional core of late-modern society for the purposes of self-preservation and the prevention of constantly arising conflicts, challenges and threats.

\section{The Crisis of Late-Modern Subjectivity: from Class-Consciousness to the Schizophrenic Subject}

The spectre of the revolution, always hovering over the political order of Modernity, draws its strength from the fact that any citizen can potentially exercise his or her inalienable right as a member of a political society to represent his interests in his personal capacity, take actions and make attempts to change the political order. For the most part, this allows the hegemonic disciplinary mechanisms to be effectively ignored or bypassed along with the regulatory procedures of political representation designed to control the political energy of the masses, which, strictly speaking, also constitute the routine institutional framework of the political order of Modernity. Active citizens and social groups that represent themselves and do not need intermediaries or representatives thus comprise the revolutionary political core of Modernity. These are the Kantian adult citizens who dare to be guided by their own minds and to act without external permits and approvals, without power of attorney and without guarantors. This individual and collective political action, proceeding according to the logic of the revolutionary rupture with approved actions and procedures, perforce reveals the constructed and conventional nature of the political order that presented itself as monolithic and unchanging in its tautological discourse. Of course, on the part of the beneficiaries of a particular political order, uncontrolled political activity and/or mobilisation of the population by non-system actors is traditionally represented as rioting teenagers, freaks, office plankton or fifth columnists, i.e. as the actions of those who reject political maturity and/or expose their conscious or unconscious dependence on foreign interests. On the other hand, the logic of street democracy is structurally analogous to the logic of a given present government, when it is shown by new leaders of public opinion that the official representatives of the people, by acting in their own, particular - not popular interests, have lost legitimacy. Thus, it is obvious that direct democracy cannot ensure the effective functioning of complex and geographically dispersed political communities of Modernity, in which representative mechanisms of expression and the harmonisation of collective interests predominate. However, the latent 
mechanisms of direct democracy come to the fore in a situation in which a political order based on representation is faced by a revolutionary crisis (Bikbov, 2012).

The revolution assumes as its key feature the emergence of alternative sources of political order (heterarchy) as a result of the rise and subsequent fall of mass political subjectivity (Kapustin, 2015, p. 7). Alternative subjects are directly connected with the permanent threat of revolution in the course of expanding and intensifying conflicts already present in society. Therefore, the dominant elite seeks to discredit any non-systemic political subject by describing it with the help of a variety of marginal and peripheral non-norm codes, whereby other actors appear as terrorists, extremists, cynics, agents of influence, youth manipulated by such agents, as lacking the necessary competencies, etc. However, even when proclaiming the pathology or death of a revolutionary political subject, the state cannot stop the movement of history. The disciplinary logic of desubjectivisation and depersonalisation, as an attempt to build a total biopolitics of power, will only lead to a growth in the accursed share of things (Baudrillard), which attracts to itself all that is excluded from the discourse of power as an indispensable element of the antinomy of power. As a result, the emergence of a revolutionary situation, in which "the revolution can be understood not as a reversal of the top and bottom, when the subordinate group or 'lower classes' suddenly intercept power or become 'the elite', but as an uprising of those segments of the population who are convinced that they are bearers of the idea of the state or 'raison d'État'" (Hestanov, 2012, p. 58). The current pessimism in assessing the possibility of a future revolution is closely connected with the problem of the disintegration of effective collective action, the political subject and the capacity of states themselves under the conditions of late Modernity (Rossiya v poiskakh ..., 2016, pp. 78-104).

The paradoxical consequences of a state strategy that seeks to monopolise political subjectivity, thus creating new actors in the revolutionary logic of heterarchy (Martianov, 2009), coexist with a number of other processes leading to an overall weakening of political subjectivity in late-modern societies. Socio-political, economic and cultural forms are increasingly breaking away from the everyday experience of individuals. This gap between the individual and society, leading to an increasing inaccessibility and unknowability of the latter, is compensated by ideology and mythology, whose significance as a connecting link of individual preferences and collective prescriptions can only increase. As a result of the revolution, society came to accept experimental social practices and concepts that previously took place at its periphery and were the object of ridicule, its carriers ignored, suppressed or persecuted. However, in the situation of the reconfiguration of the social structure, these excessive, heretical, marginal and even criminal notions turn out to be in demand by a new political order (Lobovikov, 2015). The revolution realises the structural possibilities into which the society has already matured, but at the same time it continues to think of itself in terms of the relations and hierarchies of social interests and groups, whose configurations and relationships experience ever greater deformations. On the one hand, a stalemate situation arises when modernity fails to accumulate sufficient contradictions for the political order to be disturbed by revolution 
despite the many individual conflicts by which the society may be permeated at local, national and global levels. On the other hand, when differentiation and complication occur in contemporary societies, the disintegration of public spaces makes it difficult to maintain the usual hierarchies and instead promotes revolutionary heterarchies. Simultaneously, alternative axiological grounds for the political order and common good arise and a search for new ways of assembling sociality and principles of stratification is set into motion. Small groups and groups with weak social ties begin to have more effective identities and cultural codes than blurred economic macroclasses deprived of their former political subjectivity. The natural result of these transformations is the spread of the schizophrenic type of social subject, which loses its ability to effectively organise its interests over the course of history.

The schizophrenic postmodern subject loses the ability to perceive time and think historically. Accordingly, it cannot deliver utopia, because it lacks desires or hopes that underpin collective action according to the utopian impulse (Jameson, 2004). The space of history is entirely obscured by the space of culture that simulates history. Accordingly, the actions of schizophrenic subjects (consumer class, creative class, middle class, etc.), taking place within a culturally coded space that cannot be taken for reality itself, turn out to be the actions of a predominantly symbolic order that do not - and cannot - lead to changes in the socio-political reality. As a result, they lose the ability to capture social changes in time or create revolutionary utopias oriented towards the future as an alternative to the present. However, from the standpoint of preserving the political order, the insensitivity of such a subject to the past or the future is interpreted positively, as a sign of its freedom in the present, despite occluding the entire chronological horizon of possibilities.

Summarising the interim result, we can say that revolutions do not create the political, economic and cultural order of Modernity directly. Formulating more precisely, we can remark that revolutions create new individual and social subjects, which, by virtue of their extrinsic nature relative to the Ancien Régime, are able to create a different order. However, the formation and strengthening of the new political order will inevitably be associated with the transformation and extinction of revolutionary actors. The ability to create utopias is the historical mission of a kind of political demiurge, who, by virtue of their extrinsicality to the old and new orders their intermediacy - feel themselves to be all-powerful within that specific historical moment. But the revolution in its deployment instantly corrects and dismisses its creators, as, for example, the democratically- and republicanistically-inclined French aristocracy of the second echelon: "in the terror of 1793-94, the internal horror of the Jacobins was externally manifested: they saw their terrible mistake and wanted to correct it with the guillotine, but, no matter how many heads they chopped off, they still bowed their own to the strength of the ascending social stratum. Everyone bowed to that which overpowered the revolution and reaction, which flooded the old forms and filled them with itself, because it was the only active and modern majority; Sieyès was speaking more accurately than he knew when he said that the Third Estate was 'everything'. The Third Estate - or commoners - were not born in the revolution, but were ready with their own traditions and customs, which were alien to 
the other tune of the revolutionary idea. They were treated roughly by the aristocracy and kept in third place; liberated, they trampled the dead bodies of their liberators to introduce their own order" (Herzen, 1946, p. 410).

Accordingly, the ability of the political order of late Modernity to prevent revolution is straightforward, not least due to the rapid erosion of the former social classes of the demiurge. The extrinsic - whether to pre-Modernity or to Modernity - political subject disappeared; the present domineering subjects consist wholly within Modernity. And for as long as the unpredictable revolution fails to wrest some people from Modernity, they will lack a sufficiently strong collective subjectivity, since this only arises during a revolution. Until then, political utopias will not appear, because utopias do not precede revolutions, but are formulated during their process by new actors.

Undoubtedly, prior to the outbreak of a revolution, there are political change discourses as, for example, the work of Rousseau, Voltaire and the Encyclopaedists; however, these can serve only as preliminary material for revolutionary utopias. Nevertheless, the landmark "Sketch for a Historical Picture of the Progress of the Human Mind" was only written by Nicolas de Condorcet at a time when the French Revolution was in full swing; in general, key modern ideologies took shape only as a result of subsequent reflection on the revolutionary transition to a new social state.

Thus, the prospect of a revolutionary alternative to Modernity is closely related to the possibilities for continuing the reproduction of ideologies and utopias that totalise social reality within the structures of group experience. Totalisation generates an image of society that is oriented towards the re-creation of its integrity. This is true even if the received cognitive coordinates of society are recognised by other interpreters as subjective, vulnerable and ideological. The creation of ideologies and utopias as a means of cognitive mapping, allows the subjectivity and identity of a particular social class to be recreated, including through the construction of its social coordinates relative to other classes. Conversely, the logic of preventing revolution is manifested in the form of attempts to remove conflict and class content from politics, replacing them with various palliatives in the form of homo economicus, metaphors of the natural market and various theories of modernisation. This tendency involves the introduction of universal standards into all areas of life, releasing them from historical traditions and cultural contexts.

However, a closer look proves that, on the one hand, the theory of modernisation and democratic/market transition, and, on the other hand, civilisational discourses on the insurmountability of cultural differences and ruts of tradition, are merely forced palliatives of class ideologies in the situation of the weakening and schizophrenisation of the established political subjects of Modernity. These discourses do not exist as a means to understand the particular societies in respect of which they are applied, but rather in order to make them more similar to other societies acting as a target sample. Or, alternatively, they serve to justify the unavoidable differences from the target societies, which by virtue of their uniqueness also free themselves from an understanding of their society from a comparative-historical perspective. Thus, the idea of Modernity presented in a neutral form as modernisation, i.e. the permanent achievement of an increasingly modern state of affairs, is analogous to an endless 
cul-de-sac for a society entirely lacking in utopias that go beyond economic (capitalism) or cultural (civilisation) determinism.

However, if (a) capitalism in (b) legitimising its liberal consensus and nation-state as the dominant political format of their synthesis, comprises the value-institutional quintessence of the political order of Modernity, it is precisely in challenges to (a) capitalism and (b) the liberal consensus and nationalism that the most obvious means for crystallising revolutionary movements are presented. It seems that in late-modern societies, these challenges and the corresponding ideological/utopian formats under the conditions of stagnation are increasingly likely to be determined by economic means. The geographic and technological expansion of the capitalist world system during a particular historical period (the Glorious Thirty from 19451975) made it possible to smooth out internal class contradictions through extramarket regulation and compensation for the costs of capitalism in the form of the welfare state and an expanding middle class. However, under the conditions of suspended economic growth, robotisation and a decline in the status of working people, such stabilisers cease to compensate for the growing costs and noneconomic challenges to capitalism associated with the growth of the unemployed and the precariat, as well as a decrease in the ability of states to perform protective functions for these sectors of citizens.

In his influential book One-Dimensional Man, Herbert Marcuse concluded that "underneath the conservative popular base is the substratum of the outcasts and outsiders, the exploited and persecuted of other races and other colours, the unemployed and the unemployable. They exist outside the democratic process; their life is immediate and the most real need for ending intolerable conditions and institutions. Thus, their opposition is revolutionary even if their consciousness is not." (Marcuse, 1964, pp. 260-261). Over half a century after these words were written, social forces that are ostensibly trying to torpedo it in the name of these or those alternatives continue to mature within global Modernity. These social forces comprise a wide range of radical movements (fundamentalists, alternative globalists, anarchists, new Luddites, environmentalists, different minorities, etc.), usually constructing their ideological niches in the form of private utopias aimed at solving private challenges, problems and contradictions in modern society.

It seems that in the context of this process there will be an increasingly diverse cultural determination of group interests and collective actions as well as the value of the social status and social capital of its participants. However, the particular nature of the criticism of Modernity becomes the chief problem of the global revolutionary movement. Political ultra-projects do not permit the possibility of a total alternative to Modernity, to all intents and purposes replacing it with a discourse of justice, restoration of a balance of interests, or discourses related to the repair of Modernity, but ultimately only strengthen the political order that constantly incorporates those movements into the mainstream and periodically satisfies protest demands. This problem is not resolved by the efforts of leftist forces against the backdrop of global challenges to resuscitate familiar ideological coordinates and class struggle from the times of national-industrial Modernity (Kagarlitsky, 2017, p. 264-265). If 
the lives of the majority are ipso facto significantly affected by the consequences of revolution, the field within such potential changes may take effect is becoming less and less directly related to politics. Under the conditions of late Modernity, the revolutionary potential of social change is increasingly fuelled by the possible consequences of the implementation of non-political, private utopias. This occurs, for example, when biomedical or technological progress replaces human workers in production processes, resulting in capability for work no longer comprising the basic usefulness resource of the majority of the population in the sense of providing automatic access to various benefits. Technological progress, a sharp increase in life expectancy (and consequently, in the number of disabled and old people), universal basic income, unlimited sources of energy and the management of biological mutations can have unexpected political consequences comparable to the class revolution in terms of transforming the political order and the principles of its stratification.

\section{The New Revolution as the Problem of a Political Alternative to Late Modernity}

Revolution feeds on utopia as the energy of the future. Thus, revolutions are caused by utopian discourses associated with social forces, whose constituents would like to expand their rights and opportunities by gaining control over their own destiny. However, under the conditions of late Modernity, the utopian dimension is experiencing increasing difficulties in comparison with those alternatives that make their appeal to the past and the present. The future, in common with the metanarratives associated with its justification, is increasingly being viewed as something vague, suspicious and unconvincing. As a result, it turns out that "a revolution in the usual sense is no longer possible, since there are no intentions for a break with the past and associated breakthrough into the future, dynamism is suspicious, and violence is unacceptable" (Puchkov, 2017).

The problem of the possibility of a new revolution is not only that the value of order/stability is almost always perceived to be more fundamental than the value of change. It consists in the search for an alternative that would be attractive to active social forces, which would lead to a conscious rejection of the liberal consensus of Modernity that, in one version or another, continues to dominate. Alternatives to this consensus at the present time are generally limited to partial utopias in which, instead of recognising and discussing real social and economic problems, conflicts and interests, a process of continuing mythologisation takes place. For example, this may be seen in the (conservative) form of reasoning based on the concept spiritual bonds or (liberal) calls for the redistribution of social hierarchies and resources in favour of some minority or other. Alternatively, it may be seen in the form of calls for the destruction of the social order, which often emanate from peripheral social forces or requirements that actually become ends in themselves under conditions vaguely referred to in terms of some alternative future. This leads not so much to an overcoming of Modernity as to various kickbacks from Modernity, conceded in favour of the archaising and strengthening of pre-modern and anti-modern values, 
practices and institutions, especially in societies drifting from the centre of the capitalist world-economy towards its margins and periphery.

Here, the question of the global subject of the revolutionary changes of late Modernity and its moral advantages with respect to the hegemons also remains unclear. Negation of the political order results in a transcendence of the act of cultural disavowal or revolutionary breakdown itself. Despite the growing social base from which revolutionary demands are being issued, those ideological options for the liberation of human nature from the normative order of late Modernity not related to a return to the Ancien Régime are yet to acquire a systemic character. The ability of ultra-movements to organise systemic collective action in the context of a crisis of class subjectivity and a general decline in political subjectivity in the consumer society raises multiple questions. The repudiation of ideological meta-narratives, whether from class struggle - or even from the more blurred cultural hegemony - in favour of agonistic democracy (Mouffe, 2000, pp. 80-107), actually dissolves the political subject in cultural discourses, depriving him of the necessary initial political ontology. Here another question naturally arises concerning the social regulators of a possible post-modern society, since, in the field of mechanisms of cultural domination, late Modernity is permeated with an effective mixture and eclecticisation of its entire previous ideological heritage. It turns out that late capitalism is rather successful at commodifying and expanding into fields of non-economic regulators, such as morality, law, art and politics, which are potentially capable of producing alternative non-capitalist hierarchies and orders of social life.

Finally, in favour of the political order of late Modernity against the backdrop of weak alternatives, there is a strong practical argument: never before in history have such a large proportion of the population had such opportunities to exercise individual freedom as in the present. Consequently, contemporary revolutionaries lose the struggle for the interpretation of human nature and the generation of normative ideas concerning the desires and purposes of human existence (Jameson, 1983, pp. 1-14). Thus, it is becoming increasingly difficult for new utopias entering the field of political imagination to challenge the capitalist order underpinned by the developed mass consumer culture with a call for collective political action. Therefore, the growing stagnation of global capitalism paradoxically leads to demands for a disciplinary and regulatory strengthening of the political order of nation-states. This is due to the latter being seen as counterbalances to growing discontent with the transformation of the capitalist global economy associated with rising unemployment, a precarious labour market and the intensification of various forms of geographical and social inequality.

It can be observed that the most significant threats to the political order of Modernity are generated for and by itself: "Western Modernity - first the European manifestation, then the American - has for centuries maintained the conviction that it is nothing more than contemporaneity in action and that its goal is not the effective mobilisation of resources, but rather the replacement of traditions with reason." (Touraine, 2014, p. 99) Indeed, universal reason in politics proved impossible, disintegrating into its various conflicting and class-based variants. Against the backdrop of the crisis between economic classes and within instrumental reason, ideas concerning the guaranteeing 
of commonality, universality, justice and progress on a new round of globalisation are once again returning to political nations; meanwhile, global Modernity is facing ever more insoluble challenges. As a result, a future revolution may ensue from the exhaustion of the communication and dialogue opportunities for key social actors: "a revolution begins with the negation of the other and ends with the disintegration or destruction of the negating actor; only chaos or absolute power can follow it" (Touraine, 2014, p. 112). The possibility of an active, including revolutionary, return of peoples to direct participation in their common history and collective destiny under the conditions of late Modernity remains an open and debatable political issue. However, when the mass apathy of a schizophrenic consumer subject is combined with endless modernisation as a mode of living under the conditions of Modernity, the revolutionary utopia disappears over the event horizon. A global crisis having the potential to envelop many modern societies and launch uncontrolled events seems extremely unlikely; its genesis from the contradictions of capitalism, which have already existed for 500 years, is also rather doubtful, although the corresponding forecasts are issued with enviable consistency (Wallerstein et al., 2013).

It is suggested that the possibility of a new revolution can be realised only on the basis of a putative repudiation of Modernity in favour of an alternative political project having a greater capability for universalisation and totalisation. If, in legitimising the liberal consensus and nation-state as the dominant political format of its synthesis, capitalism is the value-institutional quintessence of the political order of Modernity, it is precisely in challenges to capitalism, the liberal consensus and nationalism that provide the most obvious means for crystallising revolutionary movements. At present, despite postmodernist criticisms, the crisis of the market model of capitalism and mass democracies, the weakening of the social state and other challenges to the political order of late Modernity all relate to internal transformations or the archaisation of modern societies rather than any real alternative. Finally, the global scale of late Modernity also requires another scale to be achieved by its potential revolutionary subjects. If the modern revolution was initiated in key European polities, then revolution, as an alternative to late Modernity, presupposes a transnational rise in political subjectivity together with a corresponding coordination and institutionalisation that transcends territorial states. This presupposes the emergence of an effective counterbalance to the current global economy in the form of a future global policy, which, being subordinated to the interests of the leading national states, is still very much in its infancy. While various discourses and social groups profess to play the role of revolutionary utopias and subjects, in essence, their ability to present an alternative to Modernity remains an open question. Thus, a utopian systemic challenge to Modernity, connected with a morally more justified configuration and associated hierarchy of legitimate violence, is yet to emerge.

In the long term, a serious (and possibly revolutionary) negative correction of the political order of modern societies will be capable of producing a rental transformation of capitalism and an expansion of the rent-class stratification mechanisms associated with precarisation, along with a reduction in the social mobility trajectories and other prospects of active social groups. The present global exhaustion of the market-based 
development model, which is oriented towards the infinite expansion of profit, reveals the contours of a future society without economic growth (Policy Challenges, 2015). Robotisation has in no way compensated for the costs of technological progress in terms of filling society with superfluous people, while simultaneously turning them into increasingly dangerous classes: the precarious, the unemployed and the various minorities concealed in public policy blind spots or openly ignored by the state (Ford, 2015). The discovery of resource limits applying to free, self-regulating markets leads to an increase in protectionism and nationalism, leading to the tendency to replace market competition mechanisms with the forceful redistribution of markets and resource chains. In an increasingly entrenched society without mass labour, mass taxpayers or profitable capital, the resource crisis affecting the social state model is exacerbated. The depletion of its resource base is accompanied by a growth in statedependent social groupings. As a result, a rental political order is formed, in which market communications are replaced by hierarchical models of distributive exchanges, which are increasingly controlled by the state. Social stratification increasingly depends not on market-based class formation, but on the access of citizens and social groups to the distribution of rental resources as regulated by the state. These trends lead to the dominance of rent-seeking economic behaviour (Davydov \& Fishman, 2015). Mass behaviour associated with the search for rents that have a guaranteed status is increasingly becoming a more profitable strategy than risky entrepreneurial activity or the desire to take advantageous positions within a shrinking and increasingly unreliable labour market.

Paradoxically, the most urgent challenge faced by existing mechanisms for coordinating collective interests is the archaisation or simulation of Modernity, in which neo-patristic, neo-patrimonial models of political order unite power, law and property. A potentially revolutionary situation arises when Modernity turns into a new non-modernity that is incapable of transforming itself or effectively responding to the constantly arising challenges and threats of the volatile contemporary society. This situation becomes especially clear at the periphery of global capitalism. Here, the beneficiaries of peripheral capitalism strive to preserve the established political order, in which the radicalisation of various contradictions is intensified by their nonsolubility. To this end, political elites may attempt to freeze fluid contemporaneity (Z. Bauman), something that is impossible by definition. Such rigid and non-modular institutional states can, as a rule, only be reversed by revolutionary means. Therefore, the likelihood of a revolution is higher on the periphery of the global system, where, as a consequence of a variety of subtle sociocultural configurations, contemporary societies lack the flexibility demonstrated by the countries of the centre.

Finally, in the course of its development, the revolution always goes beyond the framework of any previous theoretical justification. Collective praxis outpaces outdated social ontologies and categorical descriptive apparatuses in favour of the imaginary establishment of society (Cornelius Castoriadis), which is gradually overgrown with a new institutional framework and legitimating self-descriptions. Therefore, in order for revolution to take place, policy must necessarily take centre stage in public life at a time when political issues have become questions of life and death. 


\section{References}

Ankersmit, F. (2002). Representational Democracy: An Aesthetic Approach to Conflict and Compromise. Common Knowledge, 8 (1), 24-46.

Bikbov, A. (2012). Predstavitel'stvo i samoupolnomocheniye [Representation and Self-Authorization]. Logos, 4, 189-229.

Davydov, D. A., \& Fishman, L. G. (2015). Gryadushcheye rentnoye obshchestvo [The Future of the Rental Society]. Svobodnaya mysl', 5, 151-164.

Wallerstein I., Collins R., Mann M., Derluguian G., \& Calhoun C. (2013). Does Capitalism Have a Future? Oxford: Oxford University Press.

Filippov, A. (2006). Triggery absolyutnykh sobytiy [Triggers of Absolute Events]. Logos, 5, 104-117.

Ford, M. (2015). Rise of the Robots: Technology and the Threat of a Jobless Future. New York: Basic Books.

Hestanov, R. (2012). Korruptsiya i revolyutsiya kak strukturnyye osnovaniya fiktsii gosudarstvennogo interesa (raison d'État) [Corruption and Revolution as Structural Bases of Fiction of State Interest (raisond'État)]. Logos, 2, 46-64.

Herzen, A.I. (1946). Byloye $i$ dumy [Past and Thoughts]. Leningrad: Gosudarstvennoye izdatel'stvo khudozhestvennoy literatury.

Goldstone, J. (2012). Revolutions: A Very Short Introduction. Oxford: Oxford University Press.

Jameson, F. (1983). Pleasure: A Political Issue. In: F. Jameson (Ed.), Formations of Pleasure (pp. 1-14). London: Routledge \& Kegan Paul Plc.

Jameson, F. (2004). The Politics of Utopia. Retrieved from: http://libcom.org/ library/politics-utopia-frederic-jameson

Kagarlitsky, B. Yu. (2017). Mezhdu klassom i diskursom. Levyye intellektualy na strazhe kapitalizma [Between the Class and the Discourse. Leftist Intellectuals guard the Capitalism]. Moscow: Izdatelskii dom Vysshey shkoly ekonomiki.

Kapustin, B.G. (2010). Sovremennost' [Modernity]. In: New Philosophical Encyclopedia (V. 3). Moscow: Thought.

Kapustin, B. G. (2015). O ponyatii «revolyutsiya» [On the Notion of "Revolution"] in Revolyutsiya kak kontsept $i$ sobytiye [Revolution as a concept and an event]. Moscow: OOO «TSIUMiNL», 6-31.

Lobovikov, V.O. (2015). Kriminologiya, istoriya filosofii i diskretnaya matematicheskaya model' formal'noy aksiologii prestupnoy deyatel'nosti («Po ponyatiyam» li myslili i zhili vydayushchiyesya filosofy?) [Criminology, the History of Philosophy and the Discrete Mathematical Model of the Formal Axiology of Criminal Activity (Were the Outstanding Philosophers Authentic Criminals?)]. Scientific 
Yearbook of the Institute of Philosophy and Law of the Ural Branch of the Russian Academy of Sciences, 15 (4), 5-24.

Luhmann, N. (2006) Differentsiatsiya [Differentiation]. Moscow: Logos.

Marcuse, G. (1964). One-Dimensional Man: Studies in Ideology of Advanced Industrial Society. London, UK: Routledge \& Kegan Paul.

Martianov, V.S. (2012). Posle postmodernizma [After Postmodernism]. Vestnik NGU. Seriya: Filosofiya, 10 (3), 64-73.

Martianov, V.S. (2012). Global'nyy Modern: ot miroekonomiki k miropolitike [Global Modernity: from the World-Economy to the World-Politics]. World Economy and International Relations, 6, 80-89.

Martianov V.S. (2009). Gosudarstvo i geterarkhiya: sub"yekty i faktory obshchestvennykh izmeneniy [The State and Heterarchy: Subjects and Factors of Social Changes]. Scientific Yearbook of the Institute of Philosophy and Law of the Ural Branch of the Russian Academy of Sciences, 9, 230-248.

Mouffe, C. (2000). The Democratic Paradox. London, UK: Verso.

Ortega y Gasset, J. (2016). Zakat revolyutsiy [The Decline of Revolutions]. History of Philosophy, 21 (2), 132-146.

Policy Challenges for the Next 50 Years. (2015). Retrieved from: http://www. oecd.org/economy/Policy-challenges-for-the-next-fifty-years.pdf

Puchkov, P. (2017). Sovremennyye "revolyutsii" / Revolyutsiya i Sovremennost' [Modern "revolutions" / Revolution and Modernity]. Retrieved from: http://gefter.ru/ archive/21809\#anchor1

Martianov, V.S., \& Fishman, L.G. (eds.) (2016). Rossiya v poiskakh ideologiy: transformatsiya tsennostnykh regulyatorov sovremennykh obshchestv [Russia in Search of Ideologies: the Transformation of Value Regulators of Modern Societies]. Moscow: Political Encyclopedia.

Skocpol, T. (1979). States and Social Revolutions: A Comparative Analysis of France, Russia and China. Cambridge University Press.

Touraine, A. (2014). Ideya revolyutsii [The Idea of Revolution]. Sotsiologicheskoye obozreniye, 13(1), 98-116.

Baudrillard, J. (1985). Modernité [Modernity]. Encyclopaedia Universalis. Paris: Encyclopaedia Universalis, Vol. 12, 424-426. 